\title{
Role of Two Efflux Proteins, ABCB1 and ABCG2, in Blood-Brain Barrier Transport of Bromocriptine in a Murine Model of MPTP-Induced Dopaminergic Degeneration
}

\author{
Sarah Vautier ${ }^{1}$, Aline Milane ${ }^{1}$, Christine Fernandez ${ }^{1,2}$, Fanchon Bourasset ${ }^{1}$, Hélène Chacun ${ }^{3}$, \\ Lucette Lacomblez ${ }^{4}$, Robert Farinottti ${ }^{1,2}$ \\ ${ }^{1}$ University Paris-Sud XI, Department of Clinical Pharmacy EA 2706, Chatenay-Malabry, France. ${ }^{2}$ Department of \\ Pharmacy, Pitie-Salpetriere Hospital, Assistance Publique - Hopitaux de Paris, Paris, France. ${ }^{3}$ University Paris-Sud XI, \\ Department of Galenic Pharmacy, Chatenay-Malabry, France. ${ }^{4}$ Neurology Unit, Pitie-Salpetriere Hospital, Assistance \\ Publique - Hopitaux de Paris, Paris, France.
}

Received August 7, 2008; Accepted August 7, 2009; Published, August 7, 2009.

\begin{abstract}
Purpose. MPTP-induced dopaminergic degeneration is an experimental model commonly used to explore Parkinson's disease. Cerebral drug transport by ABC transporters in MPTP models has never been reported. We have investigated the role of ABCB1 and ABCG2 on the bromocriptine transport through the blood-brain barrier (BBB) in a murine MPTP model. Methods. The bromocriptine transport was investigated by measuring brain and plasma concentrations of bromocriptine after ip administration in MPTP mice. The BBB integrity was controlled by measuring the brain vascular volume of two vascular space markers, $\left[{ }^{14} \mathrm{C}\right]$-sucrose and $\left[{ }^{3} \mathrm{H}\right]$-inulin, using the in situ brain perfusion technique. $\mathrm{ABCB} 1$ and ABCG2 expression in brain capillaries were measured by Western blot. Results. We have shown that in MPTP treated mice, bromocriptine is widely distributed to brain $(2.3$-fold versus control, $\mathrm{p}<0.001)$ suggesting either disruption of $\mathrm{BBB}$ or alteration of active efflux of the drug. In situ brain perfusion of $\left[{ }^{14} \mathrm{C}\right]-$ sucrose and $\left[{ }^{3} \mathrm{H}\right]$-inulin did not evidenced a BBB disruption. Studies of ABCB1 and ABCG2 activity showed that MPTP intoxication did not alter their functionality. Conversely, ABCG2 expression studied on brain capillaries from MPTP-treated mice was decreased (1.3-fold, $\mathrm{p}<0.05)$ and ABCB1 expression increased (1.43-fold, $\mathrm{p}<0.05)$ as an off-setting of brain transport. Conclusions. These data demonstrate that MPTP intoxication does not alter the BBB permeability. However, bromocriptine brain distribution is increased in MPTP animals. Hence, MPTP may interact with another transport mechanism such as uptake and/or other efflux transporters. Inflammation and Parkinson's-like lesions induced by MPTP intoxication could lead to modification of drug pharmacokinetics and have clinical consequences, such as neurotoxicity.
\end{abstract}

\section{INTRODUCTION}

Parkinson's disease (PD) is primarily a neurodegenerative disorder characterized by a large loss of nigral dopaminergic neurons with dopamine depletion and formation of Lewy bodies. PD treatment consists in the administration of dopamine receptor agonists and levodopa, as dopamine does not cross the bloodbrain barrier (BBB). It has been postulated that exogenous toxicants, including pesticides, might be involved in the etiology of PD (1). Several in vivo models of dopaminergic degeneration, using neurotoxins such as rotenone, 6hydroxydopamine (6-OHDA) or MPTP, have been developed to study PD (2-4). MPTP, and its metabolite $\mathrm{MPP}^{+}$, are potent and specific nigral toxins able to inhibit the complex I of the mitochondrial electron transport chain (5). The model of MPTP intoxication is an interesting model for the earliest phase of PD where clinical symptoms appear and neuroprotective therapy should be introduced.

Drugs used for PD treatment need to cross the brain capillary wall to be active. Only small molecules with high lipid solubility and low molecular mass $(<400 \mathrm{Da})$ cross the BBB by passive process in pharmacologically significant amounts. Many other drugs are transported across the $\mathrm{BBB}$ by an active transport. Conversely, cerebral efflux pumps are expressed on the luminal side of $\mathrm{BBB}$ endothelial cells and are responsible for the extrusion of their substrates from endothelial cells back to the blood circulation.

Corresponding Author: Sarah Vautier, University Paris-Sud XI, Faculty of Pharmacy, 5 rue Jean-Baptiste Clement, 92296 Chatenay-Malabry, France; E-mail: sarahvautier@hotmail.com 
ABBREVIATIONS

ABC Transporters: ATP-Binding Cassette Transporters ABCB1: P-glycoprotein, P-gp

ABCG2: Breast Cancer Resistance Protein, BCRP

ATP : adenosine triphosphate

BBB: Blood-brain barrier

BCT: Bromocriptine

Ip: intraperitoneal

$\mathrm{MPP}^{+}$: 1-methyl-4-phenylpyridinium

MPTP : 1-methyl-4-phenyl-1,2,3,6-tetrahydropyridine

mRNA : messenger RNA

MRP : Multidrug resistance associated proteins

PEG : polyethylene glycol

PD: Parkinson's disease

Among the efflux transporters, ABCB1 (Pglycoprotein, P-gp) and ABCG2 (Breast Cancer Resistance Protein, BCRP) are two pumps of the family of ATP-binding Cassette transporters (ABC transporters). ABCB1 was first described by Juliano et al as a chemotherapic exporter in multidrug resistant tumors (6).

Several antiparkinsonian drugs have been tested for interactions with efflux or influx transporters. Among them, levodopa and bromocriptine. Levodopa is a major treatment in PD whereas dopamine agonists are used in mild forms of disease. Bromocriptine, a dopamine agonist is still used, despite of its adverse effects, alone or combinated with levodopa.

Levodopa crosses BBB through LAT1 (Large neutral Amino-acid Transporter) and is converted in dopamine within the brain by aromatic amino acid decarboxylase (AAAD). While Soares-da-Silva et al. have shown that levodopa is excluded from brain capillary endothelial cells by $\mathrm{ABCB} 1(7,8)$, other authors showed that levodopa does not interfere with ritonavir uptake by ABCB1 expressing cells (9). Bromocriptine, an antiparkinsonian drug which is also a substrate of $\mathrm{ABCB} 1$, is weakly transported in cerebral tissues and low concentrations are detected in mice brain (10). Shiraki et al., as well as Orlowski et al. have also shown that bromocriptine interacts with $\mathrm{ABCB} 1$ in vitro (11, 12). Uhr et al. have shown that budipine, another dopamine agonist, was transported out of the brain by ABCB1 (13). ABCG2 also plays a role in drug efflux of many drugs but interactions between ABCG2 and bromocriptine have not been described.

Multidrug resistance occurs in several diseases such as inflammation, cancer or epilepsy (14-16). Pharmacoresistance is often related to ABCB1 overexpression and has been widely described in these diseases $(17,18)$. However, few data are available on the expression and function of $\mathrm{ABCB} 1$ in $\mathrm{PD}$. Alterations of $\mathrm{BBB}$ associated with a compensatory increase of $\mathrm{ABCB} 1$ expression were observed in mice exposed to the neurotoxin 6- hydroxydopamine, suggesting that brain distribution of drugs would be modified (19). Hence, the aim of this study was to investigate the transport of bromocriptine through the BBB and understand the influence of dopaminergic degeneration on its efflux by $\mathrm{ABCB} 1$ and $\mathrm{ABCG} 2$ functionality, in a model of MPTP-induced Parkinsonism syndrome. MPTP can impair BBB integrity. As large amounts of this neurotoxin are required to achieve neurodegeneration, we also had to explore BBB integrity.

\section{METHODS}

\section{Reagents}

MPTP hydrochloride, bromocriptine mesilate (BCT) and prazosin hydrochloride were purchased from Sigma-Aldrich (Saint Quentin Fallavier, France). Digoxin Nativelle ${ }^{\circledR} 0.50 \mathrm{mg} / 2$ $\mathrm{mL}$ was purchased from Procter \& Gamble Pharmaceuticals (Neuilly-sur-Seine, France). For radioactivity studies, $\quad\left[{ }^{14} \mathrm{C}\right]$-sucrose $\quad(588$ mCi.mmol $\left.{ }^{-1}\right),\left[{ }^{3} \mathrm{H}\right]$-inulin $\left(106.7 \mathrm{mCi}^{-1}\right)$ and $\left[{ }^{3} \mathrm{H}\right]$-digoxin $\quad\left(9 \mathrm{Ci}^{-\mathrm{mmol}^{-1}}, 1 \mathrm{mCi}^{-\mathrm{mL}^{-1}}\right.$ in methanol) were purchased from Perkin-Elmer (Boston, USA) and [7-methoxy- $\left.{ }^{3} \mathrm{H}\right]$-prazosin $(78$ Ci.mmol ${ }^{-1}, 1 \mathrm{mCi} \cdot \mathrm{mL}^{-1}$ in ethanol / $0.01 \mathrm{~mol} . \mathrm{L}^{-1}$ $\mathrm{HCl}(1 / 1))$ from Amersham Biosciences (Saclay, France). Valspodar (PSC833) was a gift from Novartis (Rueil-Malmaison, France). All others reagents were analytical and/or HPLC grade.

\section{Animals}

Male C57BL/6N mice (Janvier, Le Genest-SaintIsle, France), 7-8 weeks-old (25g) were used in these studies. Animal housing, handling and experimentations were performed in accordance with the European Communities Council directive of 11/24/1986 (86/609/EEC).

\section{Acute MPTP intoxication protocol}

The MPTP-treated groups received intraperitoneal (ip) injections of MPTP every 2 hours (4 x 15 $\left.\mathrm{mg} \cdot \mathrm{kg}^{-1}\right)$ and control-groups received saline solution every 2 hours (4 times, ip) with equivalent volumes at day 0 . All injections were 
given in a volume of $250 \mu \mathrm{L} / 25 \mathrm{~g}$ of body weight. This experimental model was previously validated by Rousselet et al. (20) who showed that MPTP injections led to a loss of nigral dopaminergic neurons, a reduction in striatal dopamine content and a behavioural disturbance. As reported by the authors, in this murine model, all animals exhibit an homogeneous and severe loss (90\%) of dopamine content (20). All experiences were conducted on day 7 , since MPTP and metabolites were completely excreted and neurotoxicity by close contact was void (21). Blood was collected by intracardiac puncture after anesthesia with isoflurane. The brain was collected after euthanasia. Plasma and brain samples were stored frozen at $-80^{\circ} \mathrm{C}$ until analysis.

\section{Transport study of bromocriptine through the BBB}

BCT was administered to MPTP-treated mice and saline-treated mice, at the dose of $20 \mathrm{mg} \cdot \mathrm{kg}^{-1}$ (water:methanol, 95:5, v/v). Studies were repeated on animals previously treated with a $\mathrm{ABCB} 1$ inhibitor, PSC 833 at the dose $15 \mathrm{mg} \cdot \mathrm{kg}^{-1}$ (PEG300:ethanol, 80:20, v/v) (Table 1) in order to inhibit specifically ABCB1 activity (22).

Table 1. Experimental design to explore ABCB1 functionality at the blood-brain barrier in mice with bromocriptine. * PEG300/Ethanol, 80:20, ip: intraperitoneally

\begin{tabular}{lll}
\hline Group & Pre-treatment & treatment \\
Group 1 $(\mathrm{n}=9)$ & placebo $*$ & \\
$\begin{array}{l}\text { Control mice } \\
\text { Group 2 }(\mathrm{n}=9)\end{array}$ & PSC833 $15 \mathrm{mg} / \mathrm{kg}$ ip & \\
$\begin{array}{l}\text { Control mice } \\
\text { bromocriptine } \\
\text { Group 3 }(\mathrm{n}=9)\end{array}$ & placebo $*$ & $20 \mathrm{mg} / \mathrm{kg} \mathrm{ip}$ \\
MPTP mice & & \\
Group 4 $(\mathrm{n}=9)$ & PSC833 $15 \mathrm{mg} / \mathrm{kg}$ ip & \\
MPTP mice & & \\
\hline
\end{tabular}

In each group $(\mathrm{n}=9), \quad \mathrm{BCT}$ was administered by ip route $30 \mathrm{~min}$ after PSC 833 injection, corresponding with its plasmatic $\mathrm{T}_{\max }$. The same schedule was followed for the control group.

Brain and plasma were collected 1 hour after BCT injection. BCT concentration was determined in brain and plasma by HPLC using an analytical method validated in our laboratory and previously reported (10). Briefly, the analytical separation was achieved using a Lichrospher $^{\circledR} 100$ RP18 column $(150 \times 4.6 \mathrm{~mm}, 5$ $\mu \mathrm{m})$ with a fluorimetric detection $\left(\lambda_{\mathrm{ex}}: 330 \mathrm{~nm}\right.$; $\left.\lambda_{\mathrm{em}}: 405 \mathrm{~nm}\right)$ and a mobile phase composed of water with $0.2 \%$ diethylamine $(\mathrm{pH}$ adjusted to $\mathrm{pH} 3.0)$ and acetonitrile $(70: 30, \mathrm{v} / \mathrm{v})$ running at a flow rate of $1 \mathrm{~mL} \cdot \mathrm{min}^{-1}$. BCT was extracted from brain and plasma using $\mathrm{MCX}^{\circledR}$ OASIS cartridges (60 mg, $3 \mathrm{~mL}$ ) (Waters, Millipore, Saint Quentin, France) with $1 \mathrm{~mL}$ of methanol/ammonia $(97.5: 2.5 ; \mathrm{v} / \mathrm{v})$.

Brain tissue total $\mathrm{BCT}$ was corrected for vascular contamination using the following formula:

$$
\mathrm{Q}_{\text {total brain }}=\mathrm{Q}_{\text {cap }}+\mathrm{Q}_{\text {tissue }}
$$

where $\mathrm{Q}_{\text {total brain }}$ is the total BCT amount in brain, including cerebral capillaries and cerebral tissue, $\mathrm{Q}_{\text {cap }}$ is the BCT amount in cerebral capillaries and $\mathrm{Q}_{\text {tissue }}$ is the BCT amount in brain tissue. $\mathrm{Q}_{\text {cap }}$ was calculated as:

$$
\mathrm{Q}_{\text {cap }}=\mathrm{C}_{\text {plasma }} \mathrm{V}_{\text {vasc }}
$$

where $\mathrm{V}_{\text {vasc }}$ is the brain vascular volume $\left[13 \mu \mathrm{L} . \mathrm{g}^{-1}\right.$ of cerebral tissue (23)] and $\mathrm{C}_{\text {plasma }}$ is the BCT plasma concentration. $\mathrm{Q}_{\text {cap }}$, the $\mathrm{BCT}$ amount in cerebral capillaries. $\mathrm{C}_{\text {tissue }}$ was calculated as:

$$
\mathrm{C}_{\text {tissue }}=\mathrm{Q}_{\text {tissue }} / \text { total brain weight }
$$

where $\mathrm{C}_{\text {tissue }}$ is the $\mathrm{BCT}$ concentration in brain tissue and $\mathrm{Q}_{\text {tissue }}$ is the BCT amount in brain tissue. $\mathrm{C}_{\text {tissue }}$ was used to calculate the brain/plasma ratios Kp according to

$$
\mathrm{Kp}=\mathrm{C}_{\text {tissue }} / \text { Cplasma }
$$

These ratios representing cerebral transport were then calculated and compared.

\section{Determination of the blood-brain barrier integrity by in situ brain perfusion}

MPTP-treated mice $(n=4)$ and control mice $(n=3)$ were anesthetized by ip injection of a mixture of xylazine (Bayer, Puteaux, France) and ketamine (Panpharma, Fougères, France) at $8 / 140 \mathrm{mg} \mathrm{kg}^{-1}$. Briefly, the common carotid artery was ligated on the heart side. The external carotid was ligated rostral to the occipital artery at the level of the bifurcation of the common carotid artery. Then, the right common carotid was catheterized with polyethylene tubing $(0.30 \mathrm{~mm}$ i.d. $\times 0.70 \mathrm{~mm}$ o.d.; Folioplast, Sarcelles, France) filled with heparin $\left(25 \mathrm{IU} \cdot \mathrm{mL}^{-1}\right)$. The thorax of the mouse was opened and the heart was cut. Perfusion was 
immediately started (flow rate: $2.5 \mathrm{~mL} \cdot \mathrm{min}^{-1}$ ) with the syringe containing the perfusion fluid placed in an infusion pump (Harvard pump PHD 2000, Harvard Apparatus, Holliston, MA, USA) and connected to the catheter. The perfusion fluid consisted of bicarbonate-buffered physiological saline (mM): $128 \mathrm{NaCl}, 24 \mathrm{NaHCO}_{3}, 4.2 \mathrm{KCl}, 2.4$ $\mathrm{NaH}_{2} \mathrm{PO}_{4}, 1.5 \mathrm{CaCl}_{2}, 0.9 \mathrm{MgCl}_{2}$ and 9 D-glucose. The solution was gassed with $95 \% \mathrm{O} 2$ and $5 \%$ $\mathrm{CO} 2$ for $\mathrm{pH}$ control (7.4) and warmed to $37^{\circ} \mathrm{C}$ in a water bath. Appropriate concentrations of compounds were added to the perfusate. Each mouse was perfused with $\left[{ }^{3} \mathrm{H}\right]$-inulin $(0.35$ $\left.\mu \mathrm{Ci} . \mathrm{mL}^{-1}\right)$ and $\left[{ }^{14} \mathrm{C}\right]$-sucrose $\left(0.30 \mu \mathrm{Ci} . \mathrm{mL}^{-1}\right)$. Perfusion was terminated by decapitation at $60 \mathrm{~s}$. The brain was removed from the skull and dissected out on ice. Each right cerebral hemisphere was placed in a tared vial and weighed. Aliquots of the perfusion fluid were also collected and weighed to determine tracer concentrations in the perfusate. Samples were digested in $1 \mathrm{~mL}$ of Soluène ${ }^{\circledR}$ at $50^{\circ} \mathrm{C}$ and mixed with $10 \mathrm{ml}$ of Ultima gold ${ }^{\circledR}$ counting fluid (Perkin-Elmer Life and Analytical Sciences, Boston, USA). Radioactivity was determined by liquid scintillation counting on a Beckman LS 6000 TA counter (Beckman, Galway, Ireland).

\section{Calculation of brain vascular volume (Vvasc)}

The calculation of the brain vascular volume has previously been described $(23,24)$. The brain vascular volume (Vvasc, $\left.\mu 1 . \mathrm{g}^{-1}\right)$ was assessed with $\left[{ }^{14} \mathrm{C}\right]$-sucrose and $\left[{ }^{3} \mathrm{H}\right]$-inulin, which do not cross the BBB during short exposure.

$$
\mathrm{V}_{\text {vasc }}=\mathrm{X}_{\text {brain }} / \mathrm{C}_{\text {perf }}
$$

where $X_{\text {brain }}\left(\mathrm{dpm} \cdot \mathrm{g}^{-1}\right)$ is the amount of $\left[{ }^{3} \mathrm{H}\right]-$ or $\left[{ }^{14} \mathrm{C}\right]$-compound in the right cerebral hemisphere, and $\mathrm{C}_{\text {perf }}\left(\mathrm{dpm} . \mu \mathrm{L}^{-1}\right)$ is the concentration of $\left[{ }^{14} \mathrm{C}\right]$ sucrose or $\left[{ }^{3} \mathrm{H}\right]$-inulin in the perfusion fluid.

\section{Investigation of ABCB1 and ABCG2 functionality}

A well known and validated $\mathrm{ABCB} 1$ substrate, $\left[{ }^{3} \mathrm{H}\right]$-digoxin, was administered to MPTP-treated mice and saline-treated mice, at $0.5 \mathrm{mg} / \mathrm{kg}$ $(1 \mu \mathrm{Ci} /$ mice $)$ to investigate $\mathrm{ABCB} 1$ activity. Plasma and brains were collected 6 hours after administration of $\left[{ }^{3} \mathrm{H}\right]$-digoxin. Dose and timing of sampling were extrapolated from previous published data : 6 hours were chosen as the equilibrium time of brain/plasma concentration ratio $(22,25,26)$.

On the other hand, a ABCG2 substrate, $\left[{ }^{3} \mathrm{H}\right]$-prazosin, was administered to MPTP-treated mice and saline-treated mice, at $1 \mathrm{mg} / \mathrm{kg}$ $(1 \mu \mathrm{Ci} /$ mice $)$ to investigate $\mathrm{ABCG} 2$ activity. Plasma and brains were collected 1 hour after administration of $\left[{ }^{3} \mathrm{H}\right]$-prazosin.

Samples were transferred to Ultima Gold ${ }^{\circledR}$ counting fluid for plasma and Hionic Fluor ${ }^{\circledR}$ for brains (Perkin-Elmer Life and Analytical Sciences, Boston, USA). Radioactivity was determined by liquid scintillation counting on a Beckman LS 6000 TA counter (Beckman, Galway, Ireland). Brain/plasma concentrations ratios were calculated: they represent the cerebral transfer of digoxin or prazosin.

\section{Investigation of ABCB1 and ABCG2 expression}

\section{Isolation of brain capillaries}

Brain microvessels were isolated from mice brains by using the capillary depletion method of Triguero et al. (27) with slight modifications. After euthanasia, brains were removed from mice skulls and promptly immerged in ice-cold phosphate-buffered saline (PBS; Invitrogen Corporation, Cergy-Pontoise, France). They were then cleared of cerebellum, hind- and midbrain, superficial blood vessels, and meninx. Afterwards, half of the remaining cortex was gently homogenized in ice-cold Dulbecco's modified Eagles medium/fetal calf serum (DMEM/FCS; 90:10; v:v) (Invitrogen Corporation) by using a Teflon potter. The homogenates were next centrifuged at $1,000 \mathrm{~g}$ for $10 \mathrm{~min}$. After elimination of the supernatant, pellets were homogenized in $5 \mathrm{~mL}$ of a $25 \%$ BSA solution and centrifuged again at $1,500 \mathrm{~g}$ for $20 \mathrm{~min}$. Supernatants were thereafter removed and pellets were suspended in $1 \mathrm{~mL}$ of the same icecold mixture of DMEM/FCS and filtrated at $60 \mu \mathrm{m}$. Filtrates containing brain capillaries were centrifuged at $12,000 \mathrm{~g}$ for $45 \mathrm{~min}$. Pellets of capillaries were washed and resuspended in icecold PBS. Microvessels suspensions were finally centrifuged at $12,000 \mathrm{~g}$ for $20 \mathrm{~min}$. Pellets were immediately prepared for protein extraction and semi-quantification. 


\section{Semi-quantification of $A B C B 1$ and $A B C G 2$ expression by Western Blot}

Proteins were extracted from the crude membranes with a TENTS solution (1M Tris, $0.5 \mathrm{M}$ EDTA, $3 \mathrm{M} \mathrm{NaCl}, 10 \%$ Triton, 20\% SDS) with a protease inhibitor cocktail (1 mM PMSF, 2 $\mathrm{mM}$ Benzamidine, $7.3 \mu \mathrm{M}$ pepstatine, $5 \mu \mathrm{g} / \mathrm{mL}$ aprotinin and $20 \mu \mathrm{g} / \mathrm{mL}$ leupeptin) for $60 \mathrm{~min}$ under gentle shaking. Once centrifuged (12000 rcf; $20 \mathrm{~min}$ ), the supernatants were stored at $20^{\circ} \mathrm{C}$ before quantification of total proteins using bicinchoninic acid protein assay kit (SigmaAldrich). Ten $\mu \mathrm{g}$ of proteins were dissolved in electrophoresis sample buffer containing $\beta$ mercapto-ethanol and separated on a $8 \%$ SDSPolyacrylamide gel. Resolved proteins were transferred to nitrocellulose membranes and subjected to immunoblot analysis. The blots were blocked 1 hour in TBS buffer containing $0.05 \%$ Tween 20 (TTBS) and 10\% non-fat dry milk.

After washing with TTBS, the blots were incubated 2 hours at room temperature with 1:200 dilution of monoclonal anti-ABCB1 antibody C219 (Dako, Glostrup, Denmark) or with a 1:40 dilution of monoclonal anti-ABCG2 antibody BXP-53 (Alexis, Paris, France), with a 1:5000 dilution of anti- $\beta$-actin antibody clone AC74 (Sigma-Aldrich).

After 5 times of 10 min washes in TTBS, they were further incubated 1 hour at room temperature with anti-mouse horseradish peroxidase-conjugated antibody diluted to
1:10000 (Dako, Glostrup, Denmark). The membranes were washed 5 times for $10 \mathrm{~min}$ in TTBS and then probed using the Western Lightning chemiluminescence reagent (Perkin Elmer; Courtaboeuf, France). The intensity of bands was quantified using Scion Image (NIH, Scion Corporation, Bethesda, USA) and protein expression was normalized with $\beta$-actin.

\section{Statistical analysis}

All data are expressed as mean \pm SEM. A non parametric Mann-Whitney test was used for statistical analysis. $P<0.05$ was considered statistically significant.

\section{RESULTS}

\section{Bromocriptine transport by ABCB1 through the BBB}

In group 1 (control mice treated with placebo), cerebral uptake of BCT was poor with a mean brain/plasma concentration ratio of $0.075 \pm 0.016$ $(\mathrm{n}=9)$ (Figure 1). In group 2, (control mice treated with PSC833), the inhibitor increased BCT uptake by 2.2 -fold in control mice $(0.155 \pm 0.031, \mathrm{n}=9$, $\mathrm{p}<0.02$ ). In group 3 (MPTP mice treated with placebo) the cerebral uptake of BCT was increased by 2.3 -fold compared with group 1 $(0.175 \pm 0.020, \mathrm{n}=9, \mathrm{p}<0.001)$. Conversely, no difference was observed between groups 3 and 4 (MPTP mice treated without or with PSC833).

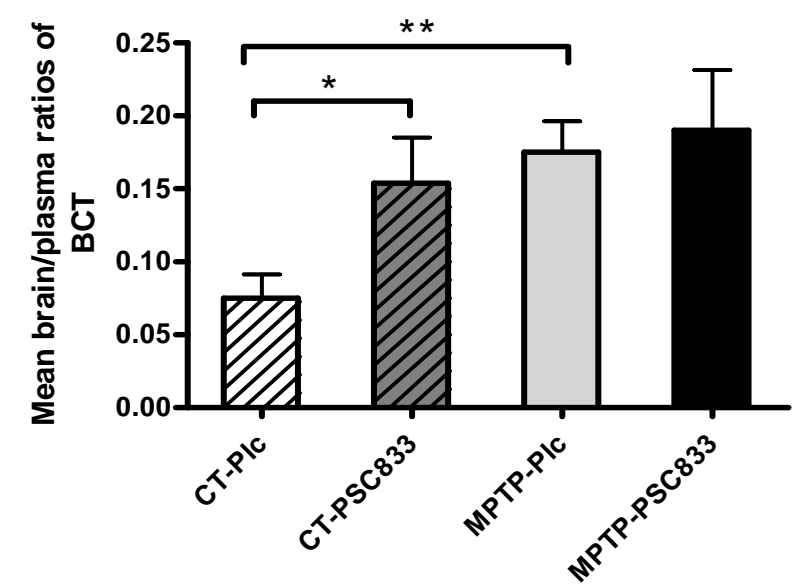

Figure 1. Brain/plasma concentration ratios of bromocriptine (BCT) (mean \pm SEM) after a single ip injection of BCT 20 mg. $\mathrm{kg}^{-1}$ to control mice treated with placebo (CT-Plc, $\mathrm{n}=9$ ), control mice treated with PSC $83315 \mathrm{mg} \cdot \mathrm{kg}^{-1}$ (CTPSC833, n=9), MPTP mice treated with placebo (MPTP-Plc, n=9) and MPTP mice treated with PSC833 15 mg.kg ${ }^{-1}$ (MPTP-PSC833, n=9), * $\mathrm{p}<0.02, * * \mathrm{p}<0.001$. Placebo: PEG300:Ethanol (80:20, v/v). 


\section{Determination of the BBB integrity by in situ brain perfusion}

$\left[{ }^{14} \mathrm{C}\right]$-sucrose and $\left[{ }^{3} \mathrm{H}\right]$-inulin were used as markers of vascular space. The vascular volume was determined in the mouse brain after a 60 second perfusion with buffer : $\mathrm{V}_{\text {vasc }}$ of sucrose $=$ $12.63 \pm 1.45 \mu \mathrm{L} . \mathrm{g}^{-1}$ in $\mathrm{CT}$ mice $(\mathrm{n}=4) \quad$ vs $12.85 \pm 0.44 \mu \mathrm{L} . \mathrm{g}^{-1}$ in MPTP mice $(\mathrm{n}=4)$ and $\mathrm{V}_{\text {vasc }}$ of inulin $=8.69 \pm 0.31 \mu \mathrm{L}^{-1}{ }^{-1}$ in CT mice vs $8.12 \pm 0.45 \mu \mathrm{L}^{-1} \mathrm{~g}^{-1}$ in MPTP mice. The vascular volumes obtained in the present study agree with previously reported values $(23,24) .\left[{ }^{14} \mathrm{C}\right]$-sucrose $\mathrm{V}_{\text {vasc }}$ were 1.4-fold higher than the $\left[{ }^{3} \mathrm{H}\right]$-inulin $\mathrm{V}_{\text {vasc, }}$ which is consistent with the study of Cattelotte et al. in which $\left[{ }^{14} \mathrm{C}\right]$-sucrose $\mathrm{V}_{\text {vasc }}$ was 1.2-fold higher than $\left[{ }^{3} \mathrm{H}\right]$-inulin $\mathrm{V}_{\text {vasc }}(24)$. This discrepancy should be attributed to the lower molecular weight and higher permeability of sucrose relative to inulin (28).

\section{ABCB1 and ABCG2 functionality}

Digoxin was chosen as a substrate of $\mathrm{ABCB} 1$ in order to investigate the functionality of this efflux pump. We did not observe any significant difference in brain/plasma ratios between MPTPtreated mice and control mice (Table 2).
Prazosin was chosen as ABCG2 substrate to investigate its functionality. We did not observe any difference in brain/plasma ratios between MPTP-treated mice and control mice (Table 2).

Inhibition of $\mathrm{ABCB} 1$ and $\mathrm{ABCG} 2$ activity was validated with PSC833 and GF120918, a specific inhibitor of ABCB1 and an inhibitor of ABCG2. We have shown that digoxin and prazosin brain transport were increased in PSC833 and in GF120918-treated animals (data not shown).

Hence, intoxication with MPTP did influence neither ABCB1 nor ABCG2 functionality.

\section{ABCB1 and ABCG2 expression at the BBB}

There was a difference in the expression of efflux transporters in cerebral capillaries of MPTPtreated mice compared to that of saline-treated mice: in brain capillaries from MPTP mice, ABCB1 expression was increased by 1.43 -fold $(p<0.05)$ when compared to that of control mice (Figure 2). On the other hand, ABCG2 expression was decreased by 1.3-fold when compared to that of control mice (Figure 3)

\begin{tabular}{|c|c|c|c|c|}
\hline \multirow[t]{2}{*}{$\begin{array}{l}\text { Efflux protein } \\
\text { tested }\end{array}$} & \multirow[t]{2}{*}{ Substrate } & \multirow[t]{2}{*}{$\begin{array}{c}\text { Number of } \\
\text { animals/group }\end{array}$} & \multicolumn{2}{|c|}{$\begin{array}{l}\text { Brain/plasma ratios } \\
(\text { mean } \pm \text { SEM })\end{array}$} \\
\hline & & & Control & MPTP \\
\hline ABCB1 & {$\left[{ }^{3} \mathrm{H}\right]$-Digoxine } & 8 & $0.22 \pm 0.05$ & $0.22 \pm 0.04$ \\
\hline ABCG2 & {$\left[{ }^{3} \mathrm{H}\right]$-Prazosin } & 12 & $0.31 \pm 0.05$ & $0.32 \pm 0.04$ \\
\hline
\end{tabular}

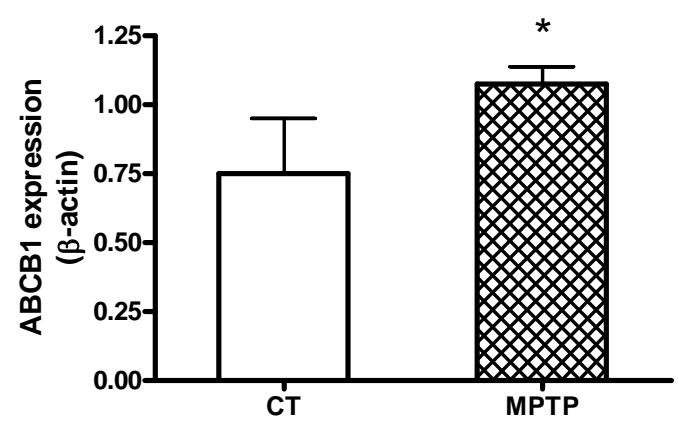

Figure 2. Effect of MPTP-induced toxicity on ABCB1 expression. The values represent mean intensities of ABCB1 expression normalized with $\beta$-actin in control group $(\mathrm{CT}, \mathrm{n}=5)$ and MPTP-treated group (MPTP, $\mathrm{n}=6){ }^{*} \mathrm{p}<0.05$. mean \pm SEM 


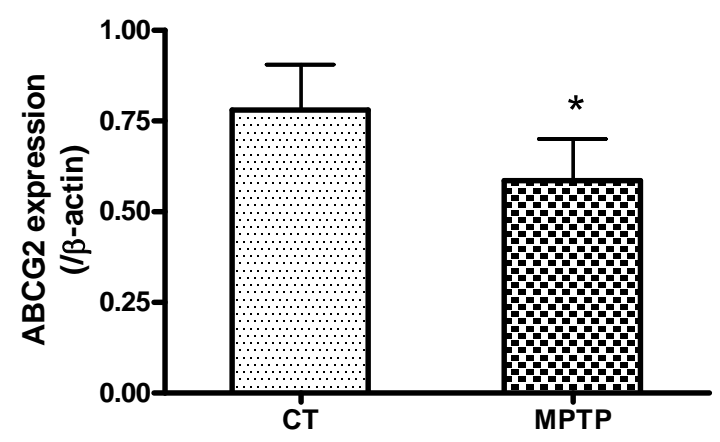

Figure 3. Effect of MPTP-induced toxicity on ABCG2 expression. The values represent mean intensities normalized with $\beta$-actin in control group (CT, $n=7$ ) and MPTP-treated group (MPTP, $n=7),{ }^{*} \mathrm{p}<0.05$. mean \pm SEM.

\section{DISCUSSION}

Our study shows that intoxication of mice with MPTP enhances brain distribution of BCT. In order to explain this phenomenon, we have hypothesized that (i) BBB permeability is increased by MPTP and/or (ii) that MPTP is responsible for an alteration of $\mathrm{BCT}$ efflux by transporters from the brain, resulting in its accumulation.

MPTP was used as a validated model of PD. Rousselet et al. have previously shown that MPTP-treated mice exhibit loss of dopaminergic neurons and dopamine content (20). In their study, they did not evidence any failure in intoxication. As we needed the whole brain to perfom drug (bromocriptine, prazosin and digoxine) or protein quantification, we could not check by immunohistochemistry to what extent were affected dopamine neurons.

As BBB permeability can influence brain diffusion of xenobiotics and may be disrupted by some toxics, we have investigated BBB integrity. $\mathrm{BBB}$ is characterized by tight junctions and adhesin molecules, between brain microvessel endothelial cells, that prohibit the crossing of xenobiotics (29). Brain vascular permeability is increased by cerebral ischemia, infections or inflammatory diseases like cerebral malaria (30). Experimental models of cerebral malaria after infection of C57BL/6N mice with Plasmodium berghei K173 have evidenced an increase of vascular permeability and cerebral oedema, permitting to epileptogene factors, to cross the BBB (30-32). MPTP was also responsible for brain inflammation that led to a second-time microglial activation which generated neuronal destruction (33). Studies using deficient mice in COX-2 gene, inductible NO synthase gene or
TNF receptors, all of them playing a role in inflammatory process, showed that blockade of microglial activation has a neuroprotective effect against MPTP toxicity (34-36). We estimated the brain vascular volume of MPTP mice by measuring the brain volume of distribution of two vascular space markers, $\left[{ }^{3} \mathrm{H}\right]$-inulin and $\left[{ }^{14} \mathrm{C}\right]$ sucrose, using the in situ brain perfusion technique. Since our BCT experiments were performed 7 days after the MPTP intoxication, we have investigated the BBB integrity at day 7 after the MPTP administration. This experiment has confirmed that the BBB was not damaged 7 days after mice were intoxicated with MPTP. But we cannot exclude that a transitory BBB disruption occurs between the day 0 and 7. Cerebral alterations in a MPTP model have been studied by Muramatsu et al. during 7 days after intoxication (37). They have shown that the neuronal NO synthetase was markedly decreased in the substantia nigra 3 and 7 days after MPTP treatment. In another rat model of glial cell degeneration, Guerin et al. have demonstrated that BBB integrity was largely re-established within 6 days after intoxication by dinitrobenzene (38). In conclusion, the increase of BCT cerebral uptake observed in our experiments could not be the outcome of an alteration of BBB integrity.

The second hypothesis to explain the increase in BCT cerebral diffusion in MPTP mice is an alteration of functionality and/or expression of efflux transporters involved in BCT cerebral transport. We have already reported elsewhere that $\mathrm{BCT}$ is transported by ABCB1 (10). The accumulation of BCT in brain of PSC833 pretreated mice confirmed this result. However, ABCB1 inhibition by PSC 833 does not modify brain distribution of BCT in MPTP-treated mice, suggesting that in these animals $\mathrm{ABCB} 1$ is not 
involved in BCT transport. Furthermore, digoxin transport is not modified by MPTP intoxication, showing that in MPTP treated animals, ABCB1 function is not altered.

In our experiments, $\mathrm{ABCB} 1$ expression was increased in MPTP animals. This increase could be explained by the inflammatory process (39). Previous works reported that MDR1 transcription could be activated by a transcriptional regulator nuclear factor for Interleukin-6 (NF-IL6), a member of the C/EBP $\beta$ family of transcription factors. NF-IL6 is inductible by stress or inflammation and would be able to induce MDR1 expression (40). ABCB1 expression is also up-regulated by the steroid xenobiotic receptor SXR (pregnant $\mathrm{X}$ receptor, PXR in rodents) which is a member of a family of ligand-activated nuclear receptor that regulate expression of drug metabolizing enzymes and transporters. This activation was demonstrated in rat brain capillaries where PXR ligands enhanced ABCB1 expression (41). Relations between MPTP or $\mathrm{MPP}^{+}$and SXR/PXR have not been described in literature. However, MPTP or MPP ${ }^{+}$ could be a PXR-ligand or another nuclear receptor ligand which up-regulates $\mathrm{ABCB} 1$ expression in brain capillaries.

The increase of $\mathrm{ABCB} 1$ expression is not followed by an increase of ABCB1 functionality as digoxin transport is not altered by MPTP intoxication. Examples of lack of correlation between $\mathrm{ABCB} 1$ expression and $\mathrm{ABCB} 1$ activity have already been reported in many assays. For instance, Regina et al. (42) have demonstrated an increase of $\mathrm{ABCB} 1$ functionality without any increase of $\mathrm{ABCB} 1$ expression after treatment of cerebral capillaries endothelial cells GPNT with dexamethasone. At the BBB level, the decrease of ABCB1 functionality without modification of the protein expression was also observed by Mandi et al. (43) on human BB19 cerebral capillary endothelial cells, after TNF- $\alpha$ treatment. MPTP could up-regulate $\mathrm{ABCB} 1$ expression but leads to the synthesis of a non functional protein. Conversely, Zhao et al. (44) have found an increase of $\mathrm{ABCB} 1$ expression with a decrease of its functionality in mice. The discrepancy between ABCB1 expression and functionality could be explained by a decrease in the ATP content in the brain or by the accumulation of endogenous $\mathrm{ABCB} 1$ substrates in plasma. In their paper, Zhao et al. retain the second hypothesis. In the same way, Staal et al. (45) have reported that $\mathrm{MPP}^{+}$is extruded from mice brain by $\mathrm{ABCB} 1$ but results have not been confirmed in vitro. However, a competition between $\mathrm{MPP}^{+}$, the active metabolite of MPTP and BCT could not explain BCT brain accumulation as on day 7 , all MPTP and MPP $^{+}$ should be eliminated. ABCB1 protein could also been overexpressed in a cytoplasmic pool but not addressed at the luminal side of endothelial cells and, so not functional.

Hence, the increase of cerebral uptake of BCT does not result from an alteration of transport via ABCB1. Recent studies have demonstrated that $\mathrm{ABCG} 2$ exerts an impact on drug absorption and disposition (46). We have demonstrated that $\mathrm{ABCG} 2$ function is not altered by the dopaminergic neurodegeneretion but its cerebral expression decreases following MPTPinduced intoxication. Literature doesn't report any case of discrepancy between ABCG2 expression and functionality.

Our studies showed that ABCB1 expression was increased whereas ABCG2 expression was decreased. Compensation between efflux transporters expression has already been described in vivo, in deficient mouse models : in mutant CF-1 mdrla(-/-) mice, the lack of in cerebral $\mathrm{ABCB} 1$ is associated with an increase of ABCG2 mRNA at the BBB compared to wildtype mice.

However, many other proteins belonging to the $\mathrm{ABC}$ transporters family are present at the BBB such as MRPs (47) or uptake transporters (organic anion transporter polypeptid Oatp2, Oatp14, LAT1) (48). We suppose that high levels of the neurotoxin MPTP, necessary to achieve the neurodegenerative model, could also alter other transporters implicated in cerebral uptake or efflux.

In conclusion, our assays show that, in a model of dopaminergic neurodegeneration, BCT brain diffusion is increased. This phenomenon which could lead to central toxicity of BCT and increase of adverse events in patients is not related to $\mathrm{ABCB} 1$ or $\mathrm{ABCG} 2$ dysfunction. Furthermore, our work gives one more example of discrepancy between ABCB1 expression and functionality.

\section{REFERENCES}

[1]. de Lau LM, Breteler MM. Epidemiology of Parkinson's disease. Lancet Neurol 5:525-35, 2006

[2]. Heikkila RE, Nicklas WJ, Vyas I, Duvoisin RC. Dopaminergic toxicity of rotenone and the 1-methyl-4-phenylpyridinium ion after their stereotaxic administration to rats: 
implication for the mechanism of 1-methyl-4phenyl-1,2,3,6-tetrahydropyridine toxicity. Neurosci Lett 62:389-94, 1985

[3]. Ungerstedt U. 6-Hydroxy-dopamine induced degeneration of central monoamine neurons. Eur J Pharmacol 5:107-10, 1968

[4]. Langston JW, Langston EB, Irwin I. MPTPinduced parkinsonism in human and nonhuman primates--clinical and experimental aspects. Acta Neurol Scand Suppl 100:49-54, 1984

[5]. Tipton KF, Singer TP. Advances in our understanding of the mechanisms of the neurotoxicity of MPTP and related compounds. J Neurochem 61:1191-206, 1993

[6]. Juliano RL, Ling V. A surface glycoprotein modulating drug permeability in Chinese hamster ovary cell mutants. Biochim Biophys Acta 455:152-62, 1976

[7]. Soares-Da-Silva P, Serrao MP. Outward transfer of dopamine precursor L-3,4dihydroxyphenylalanine (L-dopa) by native and human P-glycoprotein in LLC-PK(1) and LLC-GA5 col300 renal cells. J Pharmacol Exp Ther 293:697-704, 2000

[8]. Soares-da-Silva P, Serrao MP, Vieira-Coelho MA, Pestana M. Evidence for the involvement of P-glycoprotein on the extrusion of taken up L-DOPA in cyclosporine A treated LLC-PK1 cells. Br J Pharmacol 123:13-22, 1998

[9]. Denora N, Laquintana V, Lopedota A, Serra M, Dazzi L, Biggio G, Pal D, Mitra AK, Latrofa A, Trapani G, Liso G. Novel L-Dopa and dopamine prodrugs containing a 2phenyl-imidazopyridine moiety. Pharm Res 24:1309-24, 2007

[10]. Vautier S, Lacomblez L, Chacun H, Picard V, Gimenez F, Farinotti R, Fernandez C. Interactions between the dopamine agonist, bromocriptine and the efflux protein, $\mathrm{P}$ glycoprotein at the blood-brain barrier in the mouse. Eur J Pharm Sci 27:167-74, 2006

[11]. Orlowski S, Valente D, Garrigos M, Ezan E. Bromocriptine modulates P-glycoprotein function. Biochem Biophys Res Commun 244:481-8, 1998

[12]. Shiraki N, Okamura K, Tokunaga J, Ohmura T, Yasuda K, Kawaguchi T, Hamada A, Nakano M. Bromocriptine reverses Pglycoprotein-mediated multidrug resistance in tumor cells. Jpn J Cancer Res 93:209-15, 2002

[13]. Uhr M, Ebinger M, Rosenhagen MC, Grauer MT. The anti-Parkinson drug budipine is exported actively out of the brain by $\mathrm{P}$ glycoprotein in mice. Neurosci Lett 383:73-6, 2005

[14]. Buyse M, Radeva G, Bado A, Farinotti R. Intestinal inflammation induces adaptation of
P-glycoprotein expression and activity. Biochem Pharmacol 69:1745-54, 2005

[15]. Marie JP. Drug resistance in hematologic malignancies. Curr Opin Oncol 13:463-9, 2001

[16]. Dombrowski SM, Desai SY, Marroni M, Cucullo L, Goodrich K, Bingaman W, Mayberg MR, Bengez L, Janigro D. Overexpression of multiple drug resistance genes in endothelial cells from patients with refractory epilepsy. Epilepsia 42:1501-6, 2001

[17]. Merino V, Jimenez-Torres NV, MerinoSanjuan M. Relevance of multidrug resistance proteins on the clinical efficacy of cancer therapy. Curr Drug Deliv 1:203-12, 2004

[18]. Lee G, Bendayan R. Functional expression and localization of P-glycoprotein in the central nervous system: relevance to the pathogenesis and treatment of neurological disorders. Pharm Res 21:1313-30, 2004

[19]. Carvey PM, Zhao CH, Hendey B, Lum H, Trachtenberg J, Desai BS, Snyder J, Zhu YG, Ling ZD. 6-Hydroxydopamine-induced alterations in blood-brain barrier permeability. Eur J Neurosci 22:1158-68, 2005

[20]. Rousselet E, Joubert C, Callebert J, Parain K, Tremblay L, Orieux G, Launay JM, CohenSalmon C, Hirsch EC. Behavioral changes are not directly related to striatal monoamine levels, number of nigral neurons, or dose of parkinsonian toxin MPTP in mice. Neurobiol Dis 14:218-28, 2003

[21]. Lau YS, Novikova L, Roels C. MPTP treatment in mice does not transmit and cause Parkinsonian neurotoxicity in non-treated cagemates through close contact. Neurosci Res 52:371-8, 2005

[22]. Mayer U, Wagenaar E, Dorobek B, Beijnen JH, Borst P, Schinkel AH. Full blockade of intestinal P-glycoprotein and extensive inhibition of blood-brain barrier $\mathrm{P}$ glycoprotein by oral treatment of mice with PSC833. J Clin Invest 100:2430-6, 1997

[23]. Dagenais C, Rousselle C, Pollack GM, Scherrmann JM. Development of an in situ mouse brain perfusion model and its application to mdrla P-glycoprotein-deficient mice. J Cereb Blood Flow Metab 20:381-6, 2000

[24]. Cattelotte J, Andre P, Ouellet M, Bourasset F, Scherrmann JM, Cisternino S. In situ mouse carotid perfusion model: glucose and cholesterol transport in the eye and brain. J Cereb Blood Flow Metab 2008

[25]. Song S, Suzuki H, Kawai R, Sugiyama Y. Effect of PSC 833, a P-glycoprotein modulator, on the disposition of vincristine and digoxin in rats. Drug Metab Dispos 27:689-94, 1999 
[26]. Schinkel AH, Wagenaar E, van Deemter L, Mol CA, Borst P. Absence of the mdrla PGlycoprotein in mice affects tissue distribution and pharmacokinetics of dexamethasone, digoxin, and cyclosporin A. J Clin Invest 96:1698-705, 1995

[27]. Triguero D, Buciak J, Pardridge WM. Capillary depletion method for quantification of blood-brain barrier transport of circulating peptides and plasma proteins. J Neurochem 54:1882-8, 1990

[28]. Ohno K, Pettigrew KD, Rapoport SI. Lower limits of cerebrovascular permeability to nonelectrolytes in the conscious rat. Am J Physiol 235:H299-307, 1978

[29]. Hawkins BT, Davis TP. The blood-brain barrier/neurovascular unit in health and disease. Pharmacol Rev 57:173-85, 2005

[30]. Thumwood CM, Hunt NH, Clark IA, Cowden WB. Breakdown of the blood-brain barrier in murine cerebral malaria. Parasitology 96 ( Pt 3):579-89, 1988

[31]. Hommes OR, Obbens EA, Wijffels CC. Epileptogenic activity of sodium-folate and the blood-brain barrier in the rat. J Neurol Sci 19:63-71, 1973

[32]. Hermsen CC, Mommers E, van de Wiel T, Sauerwein RW, Eling WM. Convulsions due to increased permeability of the blood-brain barrier in experimental cerebral malaria can be prevented by splenectomy or anti-T cell treatment. J Infect Dis 178:1225-7, 1998

[33]. Wu DC, Jackson-Lewis V, Vila M, Tieu K, Teismann P, Vadseth C, Choi DK, Ischiropoulos H, Przedborski S. Blockade of microglial activation is neuroprotective in the 1-methyl-4-phenyl-1,2,3,6-tetrahydropyridine mouse model of Parkinson disease. J Neurosci 22:1763-71, 2002

[34]. Sriram K, Matheson JM, Benkovic SA, Miller DB, Luster MI, O'Callaghan JP. Mice deficient in TNF receptors are protected against dopaminergic neurotoxicity: implications for Parkinson's disease. Faseb J 16:1474-6, 2002

[35]. Dehmer T, Lindenau J, Haid S, Dichgans J, Schulz JB. Deficiency of inducible nitric oxide synthase protects against MPTP toxicity in vivo. J Neurochem 74:2213-6, 2000

[36]. Feng Z, Li D, Fung PC, Pei Z, Ramsden DB, Ho SL. COX-2-deficient mice are less prone to MPTP-neurotoxicity than wild-type mice. Neuroreport 14:1927-9, 2003

[37]. Muramatsu Y, Kurosaki R, Watanabe H, Michimata M, Matsubara M, Imai Y, Araki T. Cerebral alterations in a MPTP-mouse model of Parkinson's disease--an immunocytochemical study. J Neural Transm 110:1129-44, 2003

[38]. Guerin CJ, Nolan CC, Mavroudis G, Lister T, Davidson GM, Holton JL, Ray DE. The dynamics of blood-brain barrier breakdown in an experimental model of glial cell degeneration. Neuroscience 103:873-83, 2001

[39]. Ho EA, Piquette-Miller M. Regulation of multidrug resistance by pro-inflammatory cytokines. Curr Cancer Drug Targets 6:295311, 2006

[40]. Combates NJ, Rzepka RW, Chen YN, Cohen D. NF-IL6, a member of the C/EBP family of transcription factors, binds and trans-activates the human MDR1 gene promoter. J Biol Chem 269:29715-9, 1994

[41]. Bauer B, Hartz AM, Fricker G, Miller DS. Pregnane $\mathrm{X}$ receptor up-regulation of $\mathrm{P}$ glycoprotein expression and transport function at the blood-brain barrier. Mol Pharmacol 66:413-9, 2004

[42]. Regina A, Romero IA, Greenwood J, Adamson P, Bourre JM, Couraud PO, Roux F. Dexamethasone regulation of Pglycoprotein activity in an immortalized rat brain endothelial cell line, GPNT. J Neurochem 73:1954-63, 1999

[43]. Mandi Y, Ocsovszki I, Szabo D, Nagy Z, Nelson J, Molnar J. Nitric oxide production and MDR expression by human brain endothelial cells. Anticancer Res 18:3049-52, 1998

[44]. Zhao YL, Du J, Kanazawa H, Cen XB, Takagi K, Kitaichi K, Tatsumi Y, Ohta M, Hasegawa T. Shiga-like toxin II modifies brain distribution of a P-glycoprotein substrate, doxorubicin, and P-glycoprotein expression in mice. Brain Res 956:246-53, 2002

[45]. Staal RG, Yang JM, Hait WN, Sonsalla PK. Interactions of 1-methyl-4-phenylpyridinium and other compounds with P-glycoprotein: relevance to toxicity of 1-methyl-4-phenyl1,2,3,6-tetrahydropyridine. Brain Res 910:116-25, 2001

[46]. Xia CQ, Yang JJ, Gan LS. Breast cancer resistance protein in pharmacokinetics and drug-drug interactions. Expert Opin Drug Metab Toxicol 1:595-611, 2005

[47]. Borst P, Elferink RO. Mammalian ABC transporters in health and disease. Annu Rev Biochem 71:537-92, 2002

[48]. Gao B, Stieger B, Noe B, Fritschy JM, Meier PJ. Localization of the organic anion transporting polypeptide 2 (Oatp2) in capillary endothelium and choroid plexus epithelium of rat brain. J Histochem Cytochem 47:1255-64, 1999 